\title{
When duality of renal duplexity and duplicity coexists
}

\author{
Samarth Agarwal, ${ }^{1}$ Deepanshu Sharma, ${ }^{2}$ Ashish Sharma, ${ }^{1}$ Manmeet Singh ${ }^{1}$
}

'Department of Urology, King George's Medical University, Lucknow, Uttar Pradesh, India ${ }^{2}$ King George's Medical University, Lucknow, Uttar Pradesh, India

Correspondence to Dr Samarth Agarwal, rebellite@gmail.com

Accepted 22 August 2018

\section{DESCRIPTION}

A 25-year-old male patient presented with complaints of right flank pain and recurrent episodes of urinary tract infections (UTIs) since childhood.

He had no history of fever, haematuria, urinary incontinence or voiding lower urinary tract symptoms. Per abdominal examination was unremarkable, and there was no renal tenderness.

His complete blood haemogram and renal function tests were normal. On evaluation with ultrasound Kidney Ureter Bladder (KUB) and CT urography, there was presence of bilateral duplex kidneys with bilateral duplication of ureter with poorly functioning upper pole moiety of right duplex kidney with gross hydronephrosis and thinned out renal cortex with normal lower pole as shown in figure 1.

Tc99m-diethylenetriaminepentacetate scan was done which confirmed non-functioning upper pole moiety of right duplex kidney with invariably hydronephrotic and thinned out parenchyma.

A laparoscopic transperitoneal heminephrectomy of non-functioning moiety of right duplex kidney was performed. After the induction of general anaesthesia, cystoscopy was carried out and a $6 \mathrm{Fr}$ ureteric catheter was placed into the normal right lower ureter under fluoroscopic guidance after performing retrograde pyelography. Thereafter, the patient was positioned in a $45^{\circ}$ lateral decubitus position and three ports were placed: $12 \mathrm{~mm}$ camera port at the umbilicus, a $10 \mathrm{~mm}$ port in the line joining the umbilicus and anterior superior iliac spine, and a third 5 or $10 \mathrm{~mm}$ port subcostally completing the triangulation.

After incising the white line of toldt and moving the colon medially, the duplicated ureters were identified medial to lower pole. The gerotas fascia was incised. The normal lower pole ureter was identified by the 6 Fr catheter that was previously placed. The diseased

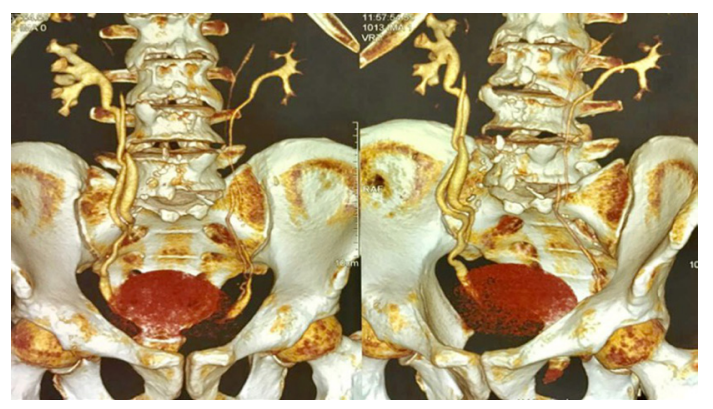

Figure 1 Three-dimensional reconstructed CT urography film showing bilateral duplex kidney with duplicated ureters with poorly functioning upper pole of right kidney. upper pole ureter was then dissected till non-functioning hilum was reached. To achieve such a meticulous dissection, we preferred using a combination of laparoscopic scissors and harmonic and staying as close as possible to serosa of the upper ureter.

Once the non-functioning renal hilum was identified, the renal artery and vein were clipped using haemolocks, two applied on each vessel. This made it easier to demarcate the upper pole non-functioning parenchyma from the functioning one. Using electrocautery and harmonic, we separated the upper pole from the rest of the renal parenchyma.

Duplex kidney is a rare entity with overall prevalence of $1 / 125$ with $20 \%$ cases being bilateral and almost twice as common in females compared with males. It is usually associated with ureteroceles, vesicoureteral reflux and ectopic ureters accompanied by a poorly functioning upper pole segment. ${ }^{1}$

The embryonic ureter develops from the ureteral bud which itself develops as a branch from the mesonephric duct. As the bud grows and reaches the trigone, it gets absorbed leaving the ureteric orifice near its normal position. In case of ureteral duplication, the caudal ureter drains the lower pole and cephalic drains the upper pole. The upper pole is more susceptible to obstruction, and the lower pole has greater association with vesicoureteric reflux. ${ }^{2}$

Because of its manifestation like UTIs, urinary incontinence and voiding dysfunction during childhood diagnosis is made early and treatment is prompt with surgical intervention leading to resolution of symptoms in most cases.

Presentation in adulthood is different with flank pain and recurrent UTIs being more common. ${ }^{3}$

For management of duplex kidney, upper pole heminephrectomy with ureterectomy if the upper pole moiety is non-functioning or

\section{Learning points}

- Bilateral duplex kidney with bilateral ureteral duplication is a rare anomaly with only a handful of reported cases, especially in adults.

- Its manifestation during childhood includes urinary tract infections (UTIs), urinary incontinence and voiding dysfunction.

- Presentation in adulthood is different with flank pain and recurrent UTIs being more common. Limited 2018. No commercial re-use. See rights and permissions. Published by BMJ.

To cite: Agarwal S,
Sharma D, Sharma A, et al.
BMJ Case Rep Published
Online First: [please
include Day Month Year].
doi:10.1136/bcr-2018-
226791

To cite: Agarwal $S_{\text {, }}$ BMJ Case Rep Published include Day Month Year 226791
For management of duplex kidney, upper pole heminephrectomy with ureterectomy if the upper pole moiety is non-functioning or ureteropyelostomy/uretero ureterostomy with ureteric common sheath reimplantation if a functioning moiety is present is the standard of care. 
ureteropyelostomy/uretero ureterostomy with ureteric common sheath reimplantation if a functioning moiety is present via open approach is the standard of care. ${ }^{3}$

Our case was unique because we performed a laparoscopic transperitoneal heminephrectomy for managing such a rare condition.

Less than 100 such cases are reported in the literature.

Contributors SA: concept, design, supervision, processing, writing, manuscript and critical analysis. DS: concept and design. AS: supervision and processing. MS: concept and supervision.

Funding The authors have not declared a specific grant for this research from any funding agency in the public, commercial or not-for-profit sectors.
Competing interests None declared.

Patient consent Obtained.

Provenance and peer review Not commissioned; externally peer reviewed.

\section{REFERENCES}

1 Brehmer B, Makris A, Jakse G. Laparoscopic heminephrectomy and resection of ectopic ureter in an adult. Urol Int 2007;79:280-3.

2 Horst M, Smith GH. Pelvi-ureteric junction obstruction in duplex kidneys. BJU Int 2008; 101:1580-4.

3 Janetschek G, Seibold J, Radmayr C, et al. Laparoscopic heminephroureterectomy in pediatric patients. J Urol 1997;158:1928-30.

Copyright 2018 BMJ Publishing Group. All rights reserved. For permission to reuse any of this content visit http://group.bmj.com/group/rights-licensing/permissions.

BMJ Case Report Fellows may re-use this article for personal use and teaching without any further permission.

Become a Fellow of BMJ Case Reports today and you can:

- Submit as many cases as you like

- Enjoy fast sympathetic peer review and rapid publication of accepted articles

- Access all the published articles

Re-use any of the published material for personal use and teaching without further permission

For information on Institutional Fellowships contact consortiasales@bmjgroup.com

Visit casereports.bmj.com for more articles like this and to become a Fellow 